\title{
Technè
}

La science au service de l'histoire de l'art et de la préservation des biens culturels

47 | 2019

Bernard Palissy : nouveaux regards sur la céramique française auX $\mathrm{XVI}{ }^{\mathrm{e}}$ et $\mathrm{XVII}{ }^{\mathrm{e}}$ siècles

\section{A Re-evaluation of 'Palissy' Ceramics at the Museum of Fine Arts, Boston}

Une réévaluation des céramiques à la manière de Palissy conservées au Museum of Fine Arts de Boston

\section{Abigail Hykin, Richard Newman and Thomas Michie}

\section{(Q) OpenEdition}

\section{Journals}

Electronic version

URL: http://journals.openedition.org/techne/1596

DOI: 10.4000/techne.1596

ISSN: 2534-5168

\section{Publisher}

C2RMF

\section{Printed version}

Date of publication: 1 June 2019

Number of pages: 126-139

ISBN: 978-2-11-152830-7

ISSN: 1254-7867

\section{Electronic reference}

Abigail Hykin, Richard Newman and Thomas Michie, " A Re-evaluation of 'Palissy' Ceramics at the Museum of Fine Arts, Boston », Technè [Online], 47 | 2019, Online since 01 June 2020, connection on 23 July 2020. URL : http://journals.openedition.org/techne/1596 ; DOI : https://doi.org/10.4000/ techne.1596

\section{cc)}

La revue Technè. La science au service de l'histoire de l'art et de la préservation des biens culturels est mise à disposition selon les termes de la Licence Creative Commons Attribution - Pas d'Utilisation Commerciale - Pas de Modification 4.0 International. 


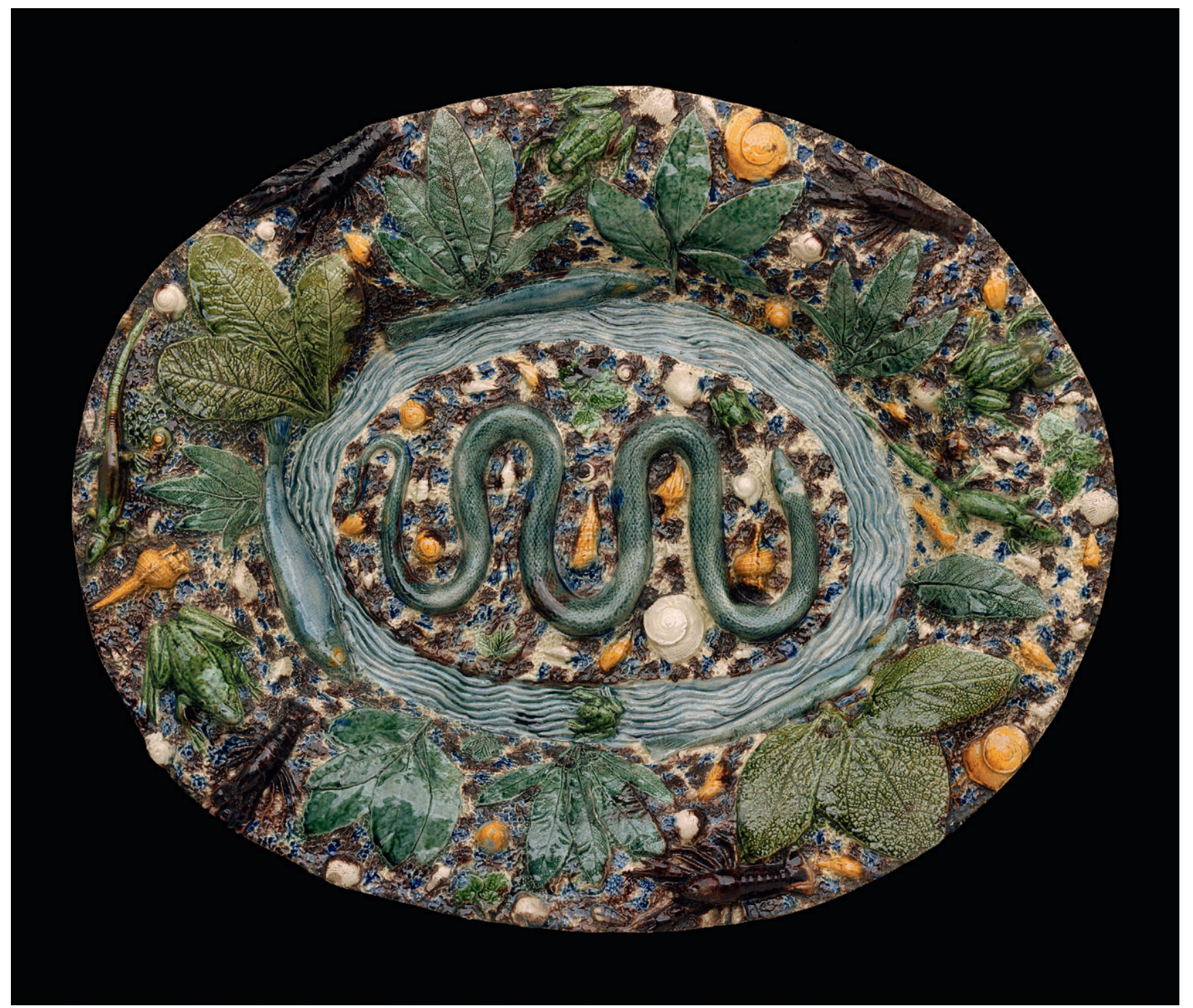

Fig. 1. France, Paris (?), first half of 17 th century, Rustic basin, lead-glazed earthenware $(44.5 \times 56.5 \times 9 \mathrm{~cm})$, Boston, Museum of Fine Arts, purchase with the Arthur Mason Knapp Fund and funds donated anonymously, MFA 60.8. () Museum of Fine Arts, Boston. 
Abigail Hykin

Richard Newman

Thomas Michie

\section{A Re-evaluation of 'Palissy' Ceramics at the Museum of Fine Arts, Boston}

Une réévaluation des céramiques à la manière de Palissy conservées au Museum of Fine Arts de Boston
Abstract. This paper reviews eleven ceramic objects in the Museum of Fine Arts, Boston (MFA) that have been attributed variously over the past 150 years to the French ceramicist Bernard Palissy (1510-1590), his studio, workshop, school, followers, circle of, or imitators. It reviews the attributions of these objects at the time of their loan or acquisition by the Museum, and examines how they fit into current research about his work. Each of the works was analyzed with non destructive, qualitative XRF and four pieces were sampled for study with SEM/EDS. These samples were further analyzed with particle-induced gamma ray spectroscopy (PIGE) at C2RMF. The analysis of one rustic platter is discussed in depth.

Keywords. Palissy, French, ceramics, provenance, analysis, SEM, XRF, PIGE, glaze, boron, sixteenth century, seventeenth century.
Résumé. Cette communication porte sur onze céramiques $d u$ Museum of Fine Arts de Boston, diversement attribuées au cours des cent cinquante dernières années à Bernard Palissy (15101590), son atelier, ses disciples, ses suiveurs, son entourage ou ses imitateurs. Nous avons examiné l'attribution de chaque céramiques à la date du dépôt ou de l'acquisition, en essayant de voir si elle était compatible avec l'état actuel de la recherche. Toutes ces œuvres ont subi une analyse qualitative non destructive par spectrométrie de fluorescence X (SFX). Des échantillons prélevés sur quatre d'entre elles ont pu être observés au miscroscope électronique à balayage couplé à un spectromètre par dispersion d'énergie (MEB-SDE). Une analyse complémentaire par spectrométrie gamma a été effectuée sur ces échantillons au C2RMF. L'analyse d'un plat à rustiques figulines fait l'objet d'une étude approfondie. Mots-clés. Palissy, céramique française, provenance, analyse, $M E B, S F X$, spectrométrie gamma, glaçure, bore, historique, $X V I^{e}$ siècle, $X V I I^{e}$ siècle.

\section{Introduction}

Like many American art museums established at the end of the nineteenth century, the Museum of Fine Arts, Boston, was modeled on the South Kensington Museum in London (now the Victoria and Albert Museum), for the purpose of educating the public, training artists, and providing sources of inspiration for industrial manufacturers. Its collecting goals have always been broadly defined, and today the collection includes works of art in all media from antiquity to the present. Incorporated in 1870, the Museum of Fine Arts grew out of the Boston Athenaeum, a membership library established in 1807 and still in operation today. Like a doting parent, the Athenaeum launched the museum, provided gallery space during its infancy, and continued to provide funds for acquisitions even after a purpose-built museum was finally erected across the city, in Copley Square. The museum opened its doors to the public on July 4, 1876, coinciding with the nation's centennial celebration. Since then, the MFA has moved only once, in 1909, to its present location in a muchexpanded building on Huntington Avenue.

The MFA has eleven ceramic objects that have been attributed variously over the past 150 years to the French ceramicist Bernard Palissy (1510-1590), his studio, workshop, school, followers, circle of, or imitators. Known for life casting to capture fish, animals, shells, and plants, along with the development of a wide range of colored glazes, Palissy achieved unprecedented naturalism in his rustic ware (rustic figulines), which continued to be imitated and copied until modern times.

The MFA's holdings range from large oval rustic basins to dishes and plaques with molded, figurative scenes based on Biblical and mythological subjects, and two small dishes with open-work (ajouré) decoration. The attribution of these objects has evolved over time, gradually moving away from the master himself to followers or an imaginary "school," as

Abigail Hykin, Richard Newman, Thomas Michie, Museum of Fine Arts, Boston (ahykin@mfa.org) (rnewman@mfa.org) (tmichie@mfa.org). 
awareness grew of contemporaneous French potteries at Fontainebleau and the nearby town of Avon. Towards the end of the nineteenth century, the work of early potteries at Manerbe and Pré-d'Auge in Normandy also began to be associated with Palissy ${ }^{1}$. Since then, works by nineteenth- and twentieth-century French imitators of Palissy, such as CharlesJean Avisseau, Georges Pull, Victor Barbizet, and Thomas Victor Sergent have been eagerly collected in their own right ${ }^{2}$. Figurative dishes and plaques are now generally accepted as products of the seventeenth century, and one can easily imagine their production extending into the eighteenth. Palissy is not known to have produced them, although many dishes and plaques with such decoration have traditionally been attributed to him and generally to his followers. The fact that molds are portable and durable and that ceramics made from them could be reproduced at any time makes precise dating or attribution of these ceramics difficult. In view of a rapidly expanding literature on "Palissy" and later "post-Palissian" ceramics, there has never been a better moment to reevaluate the ceramics traditionally associated with Bernard Palissy in the Museum of Fine Arts.

The present study of Palissyware at the MFA was spurred by the planning for a new gallery in the style of a Kunstkammer, which opened in 2014 when several of these works were examined and treated for display. All pieces were analysed by non-invasive X-ray fluorescence (XRF) for a general view of the glaze and colorants compositions. Very small samples were taken from four objects during conservation treatments for preparation as cross sections and analysis by scanning electron microscopy/energy-dispersive X-ray spectrometry (SEM-EDS). Boron, an element that cannot be detected at low levels by SEM/EDS but which may be important for dating of these wares, was analzyed in the cross sections at C2RMF by PIGE. Analytical results are discussed in the second half of this paper.

\section{Rustic ware}

Three examples of rustic ware are included in this study. A large oval rustic basin purchased in 1960 is the object in the MFA most closely associated with (or representative of) Palissy himself (fig. 1, 60.8). The plants and animals on the MFA basin display details indicating they were cast from life, and they are glazed with a wide range of naturalistic colors - especially the variety of greens of the leaves, the frogs and lizards, and brown crayfish around the rim. At the center of the basin, a baby frog is perhaps too close to the snake for its own good. The background is textured and both front and back are decorated with spots of blue, green and brown glaze. The transparency of the glazes allows the white color of the substrate and crisp details of the life casting to show through. The dish, which has no foot ring, was made by pressing an even slab of clay into a plaster mold. In view of its longstanding attribution to Bernard Palissy, this dish was thus given the most attention in terms of study and analysis.
A platter evidently made from the same mold as Boston's, but with a different glazing scheme, is in the Hermitage Museum (inv. $\mathrm{N}^{\circ} \Phi-1398$ ); it is currently attributed to a seventeenth-century "follower of Palissy" 3 . At the time of its acquisition, the MFA's platter was clearly attributed to Palissy himself. It has a distinguished provenance, beginning in 1862 with the auction in Paris of Prince Peter Soltykoff's collection and its subsequent purchase, in 1883, by English collector William Harrison Woodward. According to a paper label that Harrison signed and affixed to the back of the platter, he was acting on the advice of William Chaffers, one of the leading ceramic authorities of the nineteenth century. Recommending this purchase to the director of the MFA in 1960, curator Hanns Swarzenski expressed his belief that "it is due to the many nineteenth-century imitations and the change of fashion and taste that Palissy's fame and the market value of his ware have decreased considerably." He claimed that "such a doubtlessly authentic piece" would have "fetched at the market almost ten times as much" fifty years before ${ }^{4}$. A similar lament that the formerly high value of Palissy ceramics had been undermined by later imitations was heard as early as 1884 as the Andrew Fountaine collection was heading to auction ${ }^{5}$.

The first mention in Boston of ceramics associated with Palissy was a "curious dish" covered "with snakes, lizards and other reptiles in high relief" that was shown in an 1872 exhibition of the fledgling MFA's collection. Its identification in the catalogue as an "imitation" of Palissy suggests that the exhibition organizers were aware that it was a later production, although just how late is not known. This was probably the large oval platter (inv. No. L-ATH.1434) that remained on loan from the Athenaeum until 1976, when it was recalled and sold at auction the next year, and is therefore not part of the current study ${ }^{6}$. Perhaps inspired by that dish or by the extensive displays of foreign manufactures at the Centennial Exposition in Philadelphia, Palissy "imitations" became immediately popular in Boston and available at local shops. An 1876 newspaper notice announced that "the Bernard Palissy majolica ware so much admired at the Centennial has been imported from the Barbizet Pottery by Jones, McDuffee and Stratton, and is attracting many admirers"7 . By the $1880 \mathrm{~s}$, the firm, one of Boston leading retailers of ceramics, was lending "modern Palissy" to the MFA for display with other modern French pottery ${ }^{8}$. There was even a Boston artist, François B. De Blois (ca. 1834-1913), "a skillful modeler in clay," who in the 1890 s began to produce a variety of ceramic shapes, including rustic basins, in the style of Palissy ${ }^{9}$. Indeed, Bostonians clearly had been familiar with the life and work of Palissy since at least the 1850 s as early biographies and translations of his writings into English were published in Boston, and these and subsequent titles were regularly acquired by local libraries and private collectors ${ }^{10}$.

The first gifts (as opposed to loans) of "Palissy" ceramics to the MFA are listed in the Museum's annual report for 1893 as "two pieces of Palissy ware" presented by Susan Cornelia Warren (1825-1901). One of them, an unmarked rustic basin (fig. 2, 93.1138) with a snake on an island surrounded by 
swimming fish, frogs, a lizard, three different types of beetles, a large fly, butterfly, and dragonfly on a blue background, is now recognized as a nineteenth-century work in the manner of Palissy. Some elements of the dish, such as the shells and the smaller fish, appear to be cast from life while much of the fauna is clearly modeled, with less distinct details and at disproportionate sizes (e.g., the fly). The larger freshwater fish (a pike?) has small hexagonal "scales" that were probably created by pressing fabric or another material into the damp clay. The glaze has an uneven sheen, with the darkest matte green areas (lizard) possibly overfired. XRF shows that some of the glaze colors contain tin. The footring is pierced in two locations, allowing it to hang either horizontally or vertically. The underside is covered with thin washes of dark glaze but is not mottled. The flaring rim has a rough, stippled texture that resembles nineteenth-century imitations of rustic basins by Barbizet and Sergent from around 1880 .

Mrs. Warren presented other gifts to the Museum that she had purchased at the Centennial Exposition in Philadelphia, and it is quite possible that she was among those Bostonians who admired Palissy wares by Barbizet at the World's Fair. Her other gift of "Palissy" ware was a small dish (fig. 3, 93.1139) with a dark blue center surrounded by an open-work border (ajouré). On a similar dish in the Louvre (OA 1373), motifs such as the coiled rope and basketweave border, radiating openwork panels, and the flowers between them are larger and more crisply modeled. The differences suggest that the overall design, but not the

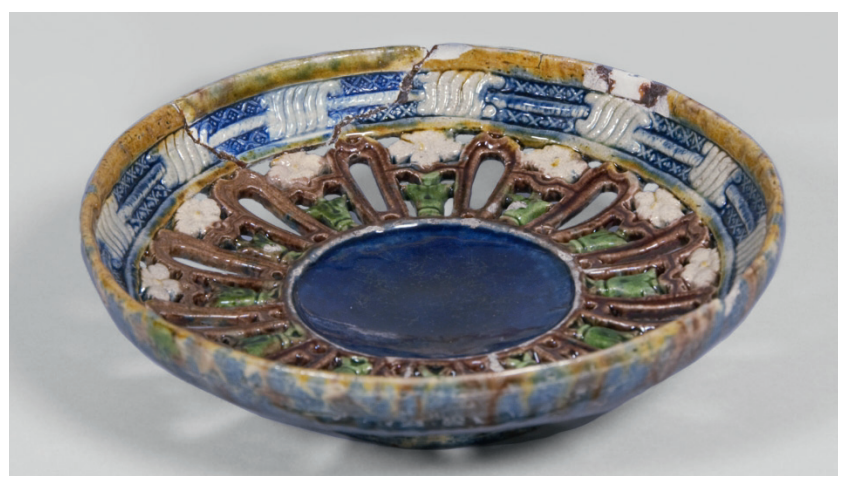

Fig. 3. France, Paris (?), first half of 17 th century, Openwork dish, lead-glazed earthenware $(5.5 \times 19.6 \mathrm{~cm})$, Boston, Museum of Fine Arts, Gift of Mrs. S. D. Warren, MFA 93.1139. The dish is shown during treatment, note the ceramic restoration at the rim. (c) Museum of Fine Arts, Boston. details, of the MFA dish were adapted from this model, whereas a dish from around 1870 in the Musée National Adrien Dubouché (ADL 7626) appears to match the Louvre dish more closely and may have been cast directly from one like it. A curious detail of this open-work dish, discovered during its recent treatment, was a glazed fragment matching the design and glaze of the rest of the plate, but with a slightly different curvature, that was inserted to fill a large loss at the $\operatorname{rim}^{11}$. With edges filed to fit the loss, the fragment may have been taken from another plate, perhaps one that was broken and used for "parts" to make such repairs. The Warren openwork dish formed part of the legendary collection of medieval and Renaissance art amassed by Fréderic Spitzer (1815-1891) and it appears in the catalog of Spitzer's "faiences par B. Palissy" compiled by Émile Molinier prior to their sale in May $1893^{12}$.

\section{Other ware: biblical and allegorical scenes and ajouré}

Among the early loans to the MFA was a figurative plate with the Sacrifice of Isaac, lent in 1888 by Mrs. William Hastings Hughes, the English wife of a Boston wine merchant then living in London. This plate was included in that year's Loan Exhibition and has been at the MFA ever since (fig. 4, $2017.497)^{13}$. The MFA's dish is in poor condition with copper staples joining multiple fragments, repairs that certainly predate its nineteenth-century loan to the museum. There are at least nine other versions of this subject in both vertical and horizontal formats, variously dated to the sixteenth and 


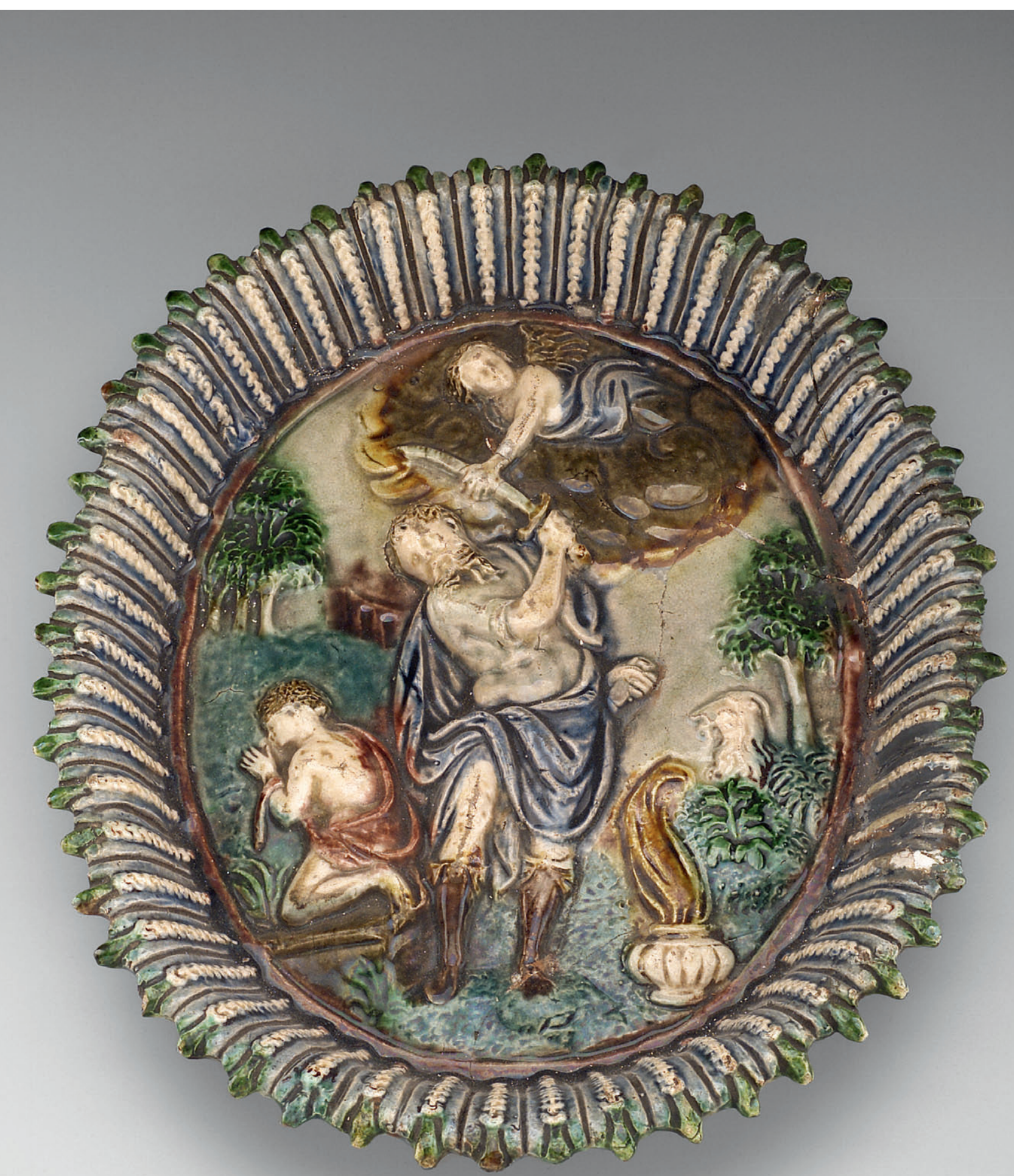

Fig. 4. France, Paris (?), first half of 17th century, Dish with Sacrifice of Isaac, lead-glazed earthenware $(24 \times 5 \times 28.7 \mathrm{~cm})$, Boston, Museum of Fine Arts, Gift of Henry H. Marshal, MFA 2017.497. @ Museum of Fine Arts, Boston. 
Fig. 5. France, Paris (?), first half of 17 th century, Dish with Susanna and the Elders, lead-glazed earthenware $(29.5 \mathrm{x} 4 \mathrm{x}$ $25 \mathrm{~cm})$, Boston, Museum of Fine Arts, The John Pickering Lyman Collection, Gift of Miss Theodora Lyman, MFA 19.1238. (C) Museum of Fine Arts, Boston.

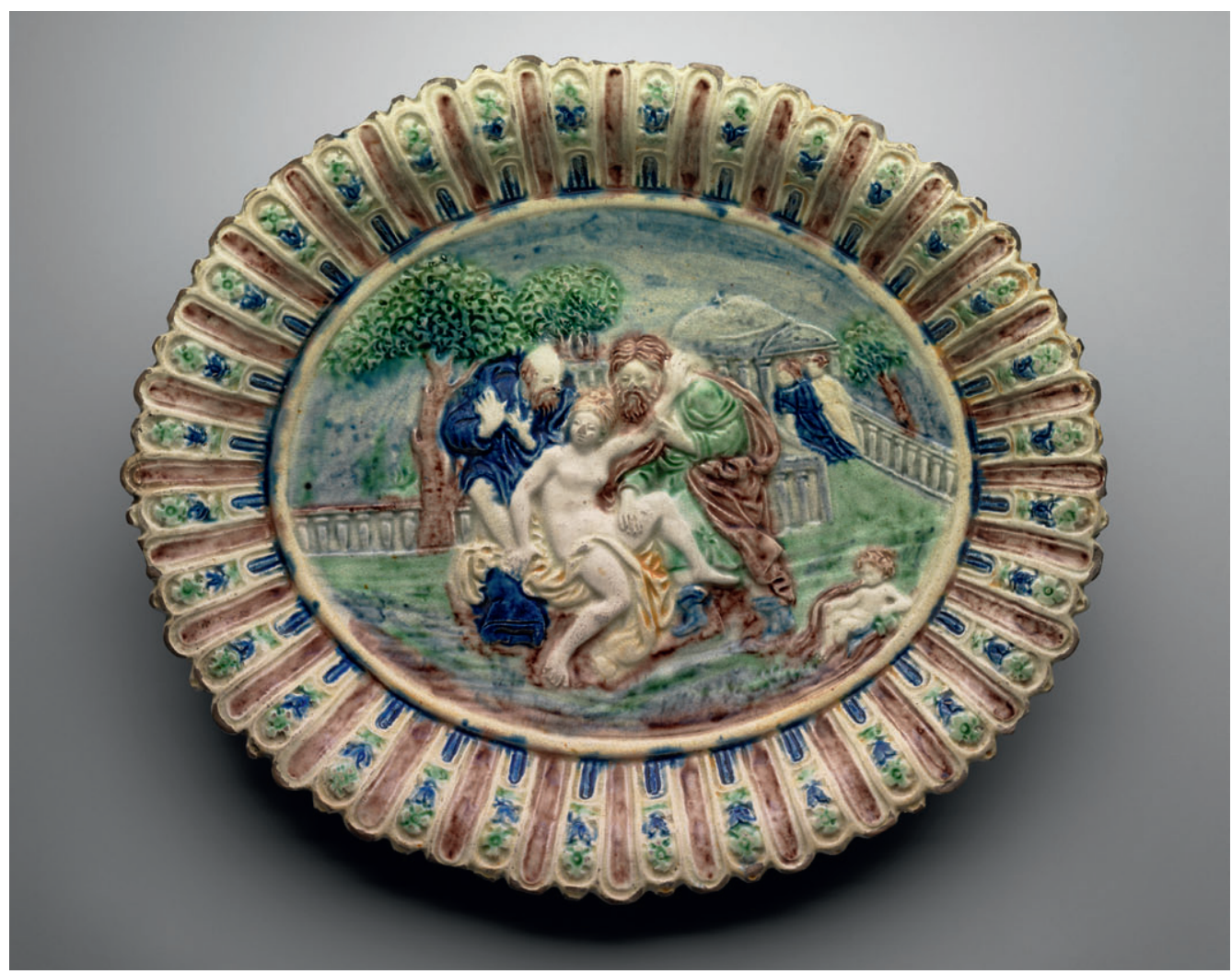

seventeenth centuries. Compared to similar plates in the collections of the Louvre (MRR 148), Cleveland Museum of Art (1975.32), and the Fine Arts Museums of San Francisco (1945.669), the MFA plate lacks many details, such as the buildings on the horizon, the wings of the angel, and the clouds surrounding the angel. Other details, such as the vessel with trailing smoke at the lower right and the trees at both left and right, have also been simplified, suggesting this is a seventeenth-century adaptation of an earlier model. Nevertheless, the Boston dish shares many features with an oval dish at Sèvres (MNC 4967) currently dated to the sixteenth century. Not surprisingly, dishes with the same scene oriented horizontally (Louvre, OA 1323; musée national de porcelaine Adrien Dubouché, ADL 159) depart from vertical dishes in order to fill the extended area at either side, as does a circular plate with this subject (musée des BeauxArts, Bernay, 866.1.105).

An early gift of "Palissy" ware to the MFA was an oval plate whose center is decorated with a low-relief scene of Susanna and the Elders, presented in 1919 by Miss Theodora Lyman as part of a large group of more than five hundred ceramics collected by her older brother John Pickering Lyman (18471914), a Boston banker (fig. 5, 19.1238). This plate was initially catalogued by the Museum as "Palissy style," and the catalogue record was later inscribed "by Dupré," presumably referring to Guillaume Dupré, the leading medalist and sculptor at the Fontainebleau court of Henry IV and son-in-law of another court sculptor, Barthélemy Prieur ${ }^{14}$. Like the previous rustic platter, the foot rim of this dish was pierced with holes for hanging before it was glazed. The molded, low-relief figures are not well defined, nor are the architectural elements in the background. A similar plate dated to the seventeenth century at the Hermitage Museum (inv. $\mathrm{N}^{\circ} \phi$-2323) suggests the re-use

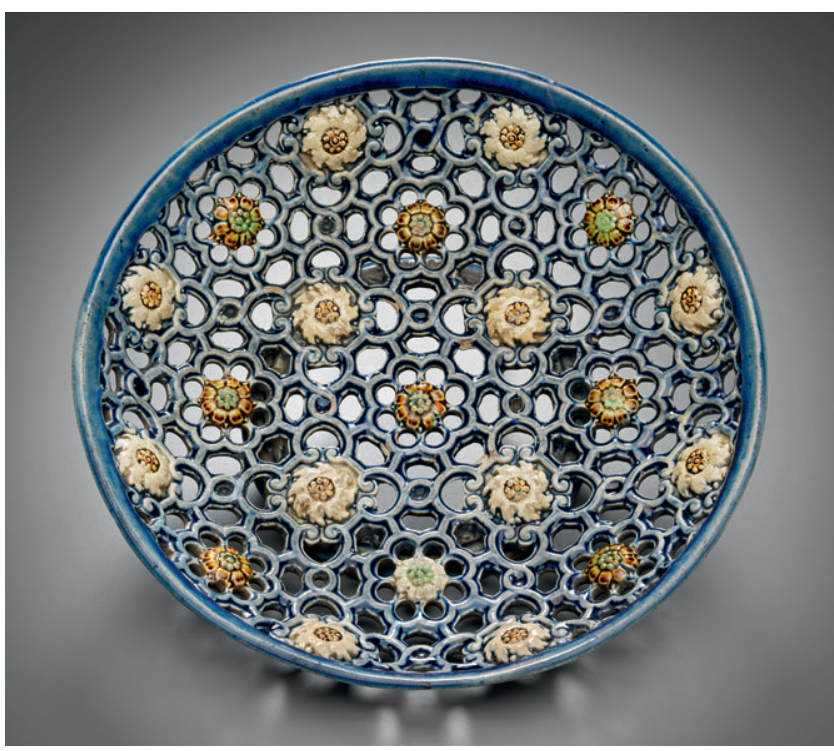

Fig. 6. France, Paris (?), first half of 17 th century, Openwork dish, lead-glazed earthenware (D. $21.6 \mathrm{~cm}$ ), Boston, Museum of Fine Arts, Arthur Mason Knapp Fund, MFA 41.106. (C) Museum of Fine Arts, Boston. 


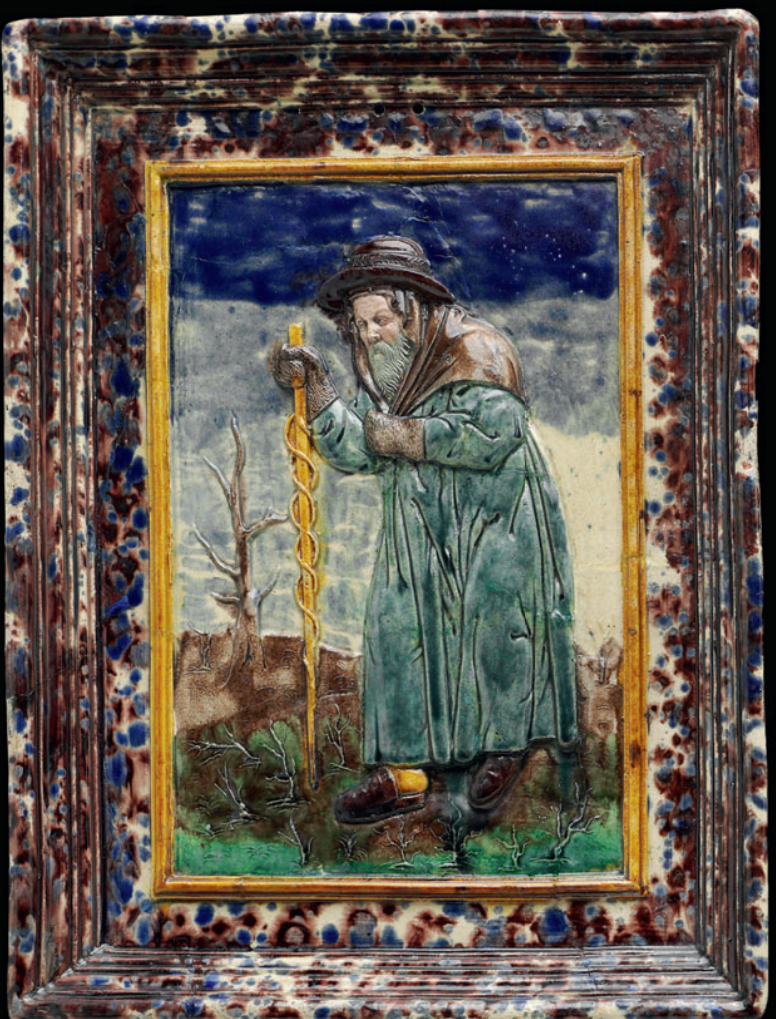

a

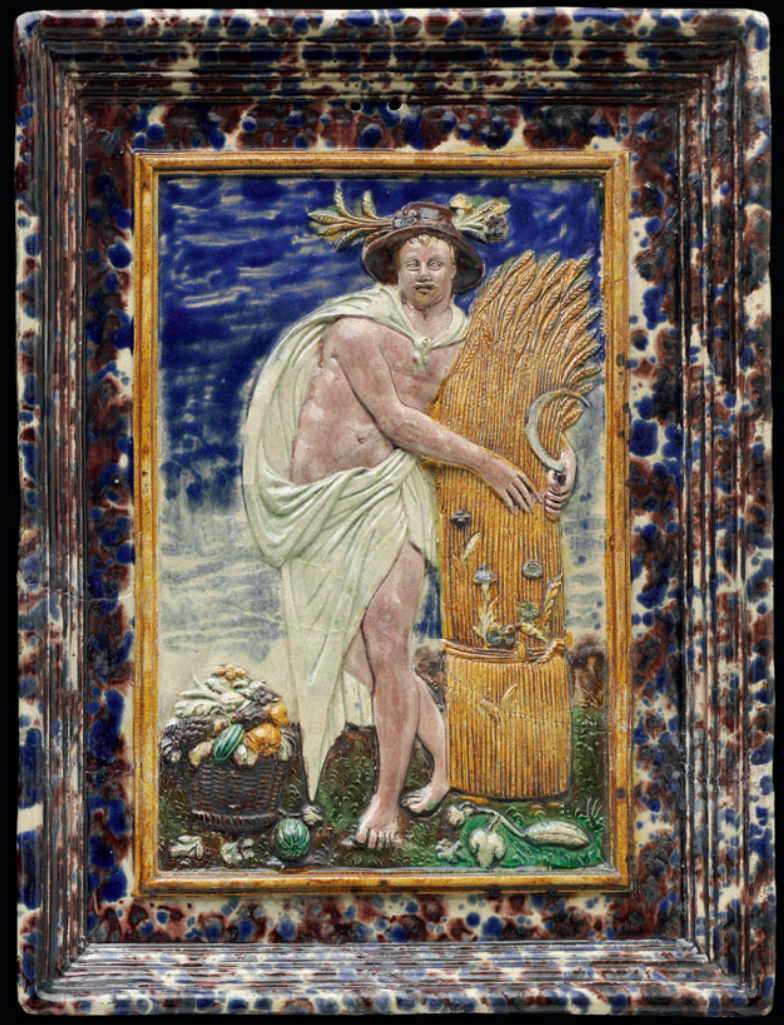

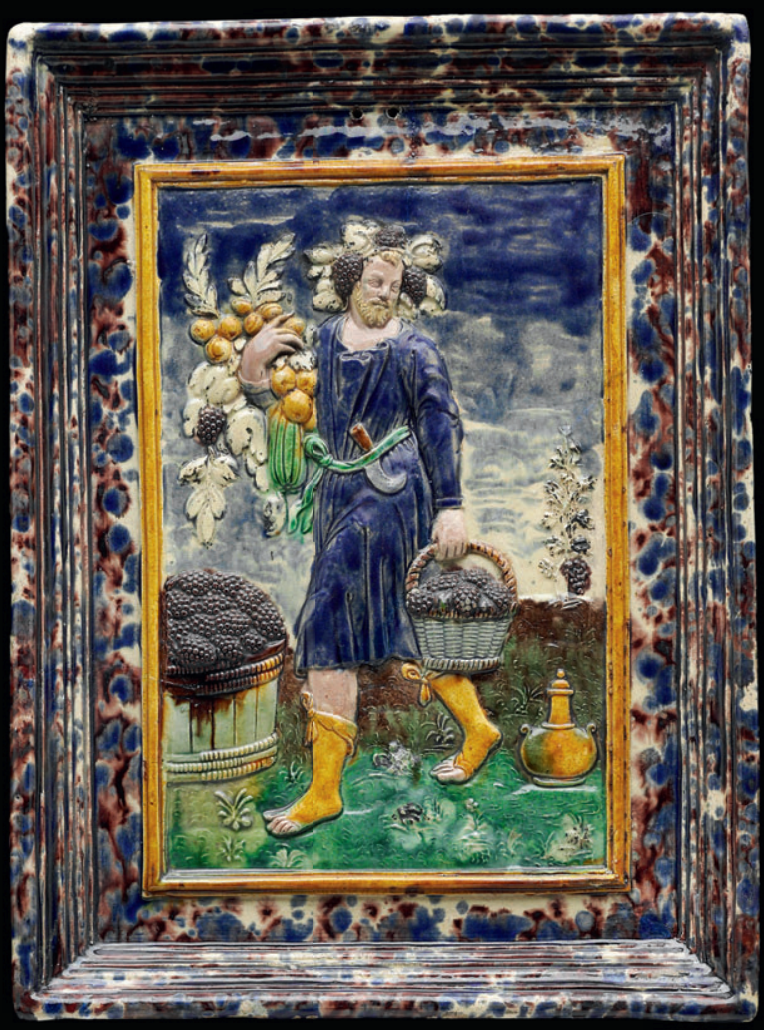

b

Fig. 7 a-d. France, Paris (?), first half of 17th century, Set of four plaques, lead-glazed earthenware, Boston, Museum of Fine Arts, H. E. Bolles Fund. a. Plaque representing Winter (31.27 x $23.65 \mathrm{~cm})$, MFA 46.56 ; b. Plaque representing Autumn $(30.95 \times 23.33 \mathrm{~cm})$, MFA 46.54 ; c. Plaque representing Summer $(31.27 \times 23.18 \mathrm{~cm})$, MFA 46.55 ; d. (facing page) Plaque representing Fire (32.86 x $24.92 \mathrm{~cm})$, MFA 46.53 . (c) Museum of Fine Arts, Boston. 


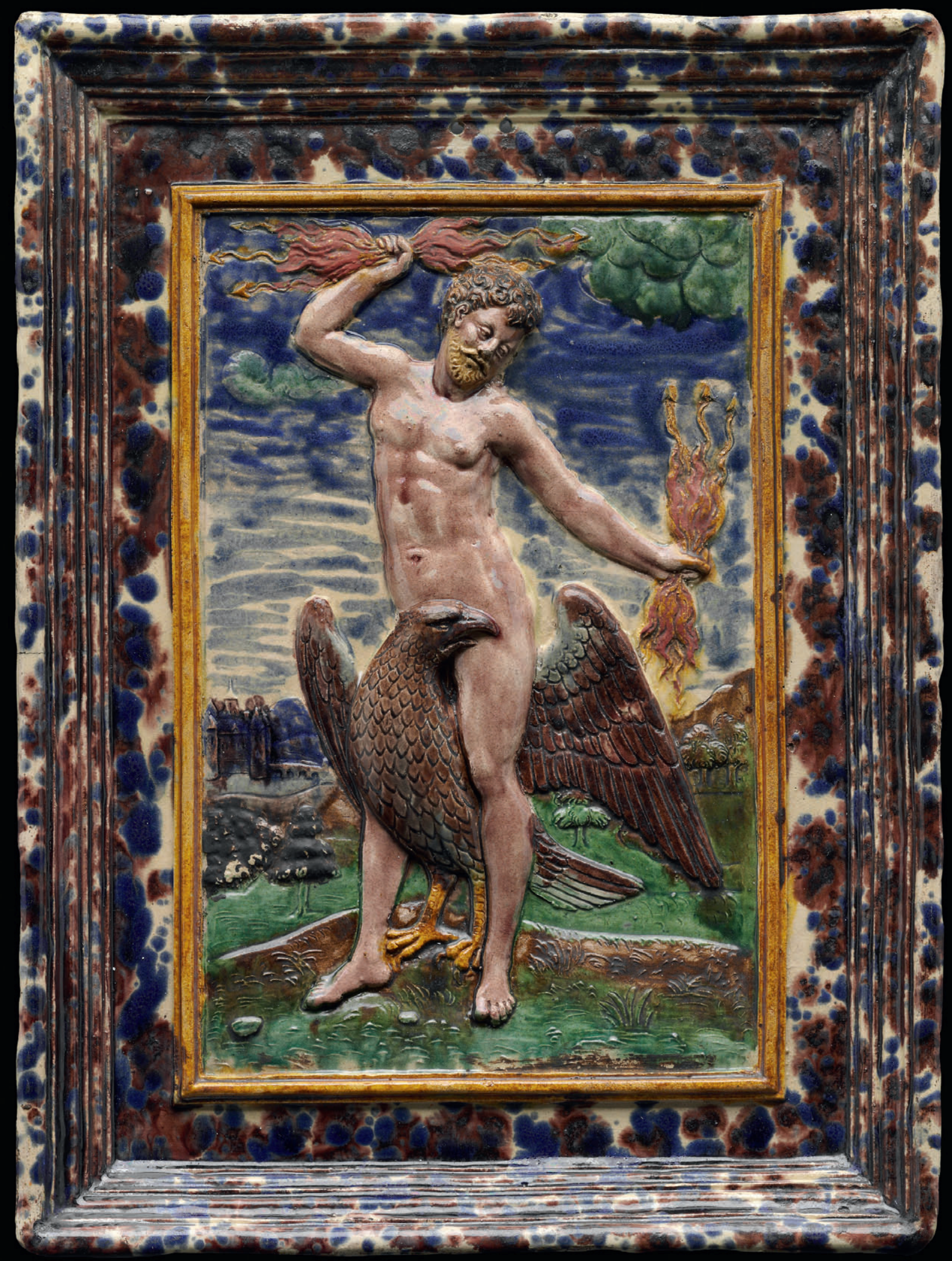




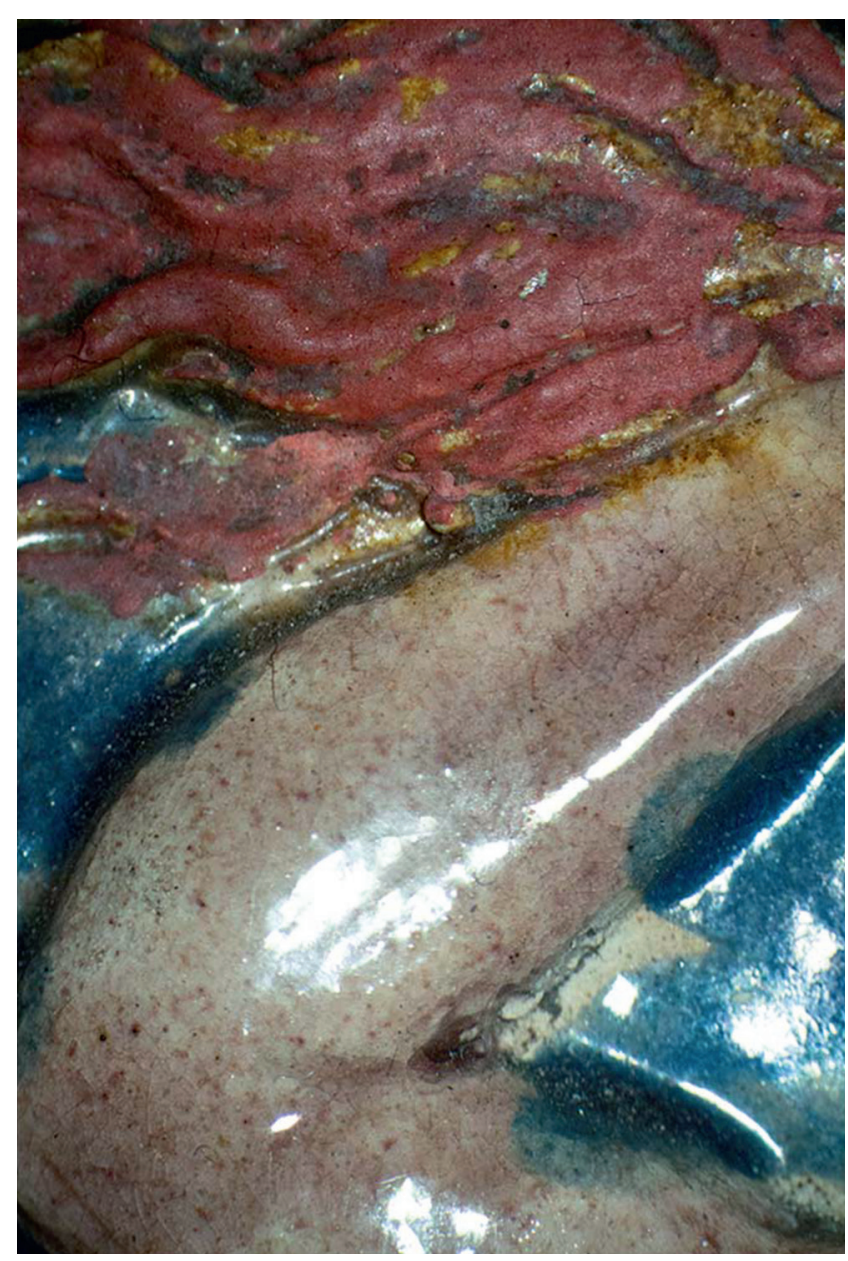

Fig. 8. Detail of figure $7 \mathrm{~d}$, Plaque representing Fire, showing red paint over yellow glaze. (c) Museum of Fine Arts, Boston.

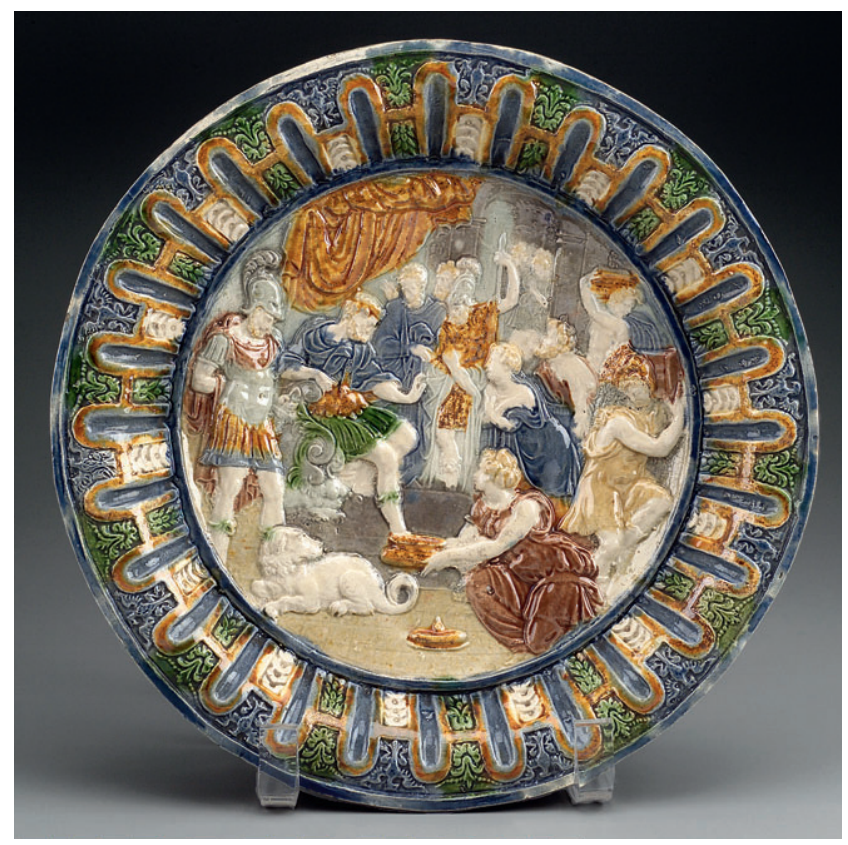

Fig. 9. France, Paris (?), first half of 17 th century, Dish with Queen of Sheba, lead-glazed earthenware $(5 \mathrm{~cm} \times 26.1 \mathrm{~cm})$, Boston, Museum of Fine Arts, Gift of Mrs. Edward Pickman, MFA 62.806. (c) Museum of Fine Arts, Boston. of molds and compositions over time, resulting in blurred details that can be difficult to decipher unless one has the benefit of comparing multiple versions of the same subject.

It was not until 1941 that the MFA made its first direct purchase of "Palissy ware," a footed, open-work dish formerly in the collection of Gustave de Rothschild and sold at auction by his grandson's wife, Baroness Lambert (fig. 6, 41.106). It was exhibited in 1900 at the Exposition universelle in Paris and retains a fragmentary label from the retrospective exhibition of French art held that year at the Petit Palais. At the time of the Lambert sale, MFA curator Georg Swarzenski expressed to the director his conviction that the dish "belongs to the few Palissy pieces whose authenticity cannot be doubted and it is exceptionally tasteful"15. Two similar dishes at the Metropolitan Museum of Art (17.190.1750 and 53.225.46), dated to the early seventeenth century, are identified as "in the manner of Palissy." One appealing anomaly of the MFA's dish is that the regular pattern of larger yellow flowers alternating with smaller white ones against a blue background is interrupted by one misplaced white flower (be it mis-glazed or intentional).

Five years later, in 1946, Georg Swarzenski purchased a group of four rectangular plaques with figures representing three of the four Seasons, plus Fire, presumably from a related series of the Elements (fig. 7a-d, 46.53-56). The plaques had also been in the Gustave de Rothschild collection and were later sold to the Museum by French and Company for considerably more than the cost of the modest dish the Museum purchased at auction. The four plaques were well known from Alexandre Sauzay and Henri Delange's monograph on Palissy (1862), where they are illustrated in a lavish, full-page chromolithograph. Our plaques with rectangular "frames" glazed in imitation of agate have a sharpness to the casting that suggests they had metal patterns. As with all the figurative pieces at the MFA, hanging holes allowed these plaques to be displayed like pictures.

During conservation treatment in 2014, remains of cold painting were discovered on three of the four plaques ${ }^{16}$. A thick, matte red paint, identifed by FT-IR as a mixture of vermillion and lead white in an oil and egg yolk binder, is found over the yellow glaze of Jupiter's thunderbolts in the plaque representing Fire (fig. 8, detail). Paint was also found on the plaques of Summer and Autumn (but not Winter), with traces of the same red over yellow glazed fruit and flowers. A dark green-brown pigment mixture containing malachite, hematite and dolomite is present on trees, grass and leaves in areas which should clearly have been green but appear white with transparent glaze over the white clay body. The application of red paint post-firing makes sense, since red glazes were notoriously difficult and not commonly in use in Europe at the end of the sixteenth or beginning of the seventeenth century, but the darker mixture is more puzzling. It is possible that the artist was looking for a particular shade, visual effect, or level of precision that could not be achieved with the glaze. 
Versions of the Summer and Autumn plaques, made as oval dishes with flaring rims instead of molded borders that imitate a picture frame, are in the Metropolitan Museum of Art $(53.225 .63, .65)$ and dated to the second half of the seventeenth century "or later."

Finally, the most recent acquisition of so-called Palissy ware is a circular dish with low-relief figural decoration of King Solomon and the Queen of Sheba (fig. 9, 62.806) donated to the MFA in 1962 by Hester (Mrs. Edward) Pickman, a Boston artist who had lived in Paris with her husband in the 1920s and whose father-in-law, Dudley Leavitt Pickman (18501938), was a major collector of European porcelain that he donated to the MFA between 1911 and 1923. Raised, rough areas around some figures, such as the load-bearing servant at the far right, suggest a rush to glaze before cleaning the surface after it was pulled from the mold and are in contrast to the extremely sharp and crisp details of the molded scene. This dish also has an interesting range of glaze colors from shades of muted grays and blues, to an intense orange (lead antimonite). Only one other dish of this subject has been located (musée d'Art et d'Archéologie de Guéret, 2009-2$57)^{17}$. Perhaps more than the dish with "Susanna and the Elders," this crowded composition of attenuated figures in a Mannerist style suggests the work of a medalist such as Dupré or perhaps an actual late Renaissance or seventeenth-century plaquette served as a model.

\section{Analysis - Overview}

Qualitative compositions of glazes on most of the objects discussed in this paper were determined by X-ray fluorescence $(\mathrm{XRF})^{18}$. In addition, small samples taken from four objects (taken from areas of existing loss or damage) have been prepared as polished cross sections and analyzed by SEM/EDS, which allows quantitative compositions of glazes to be determined; when included in a cross section, the underlying ceramic substrate can also be analyzed ${ }^{19}$.

Palissy's ceramic bodies varied from ones that fired pure white, as seen in all the MFA examples, to ones with substantial iron contents that fired brick red ${ }^{20}$. After bisque firing, Palissy applied a sometimes astonishing variety of colored glazes, which were fixed with a second firing. The lead silicate glazes, with rather variable alkali contents, were not unlike general formulations utilized by ceramicists of earlier periods in France and elsewhere. Palissy occasionally used glazes opacified with tin oxide, a very common practice among ceramicists; but glazes (even on the same object) could contain no tin and were transparent ${ }^{21}$. Palissy also produced some partially opacified glazes by adding calcium sulfate to the formulations ${ }^{22}$.

The discovery of Palissy's workshop on the grounds of the Louvre during expansions in the 1980s unearthed large numbers of fragments that provide information on his ceramic and glaze formulations. Based on analysis of excavated material and a few objects that can definitely be assigned to
Palissy himself, Bouquillon et al. have remarked that Palissy tended to use glazes with a wide range of $\mathrm{Pb}$ to $\mathrm{Si}$ ratios in single objects, while objects made by other ceramicists working in the Palissy style contain glazes that had a more restricted range of compositions (within a specific object) ${ }^{23}$. There seem to be no major differences in colorants between Palissy and followers, until the advent of the new colorant chromium in greens beginning in the early nineteenth century. Lead-antimony oxide yellows were apparently not used by Palissy, although they had been common in earlier periods and were also used by other ceramicists after Palissy. Published work on European cobalt sources and processing suggests that Palissy's blues likely would contain readily detectable arsenic, which they $\mathrm{do}^{24}$. It has been suggested that some of his blues were made from blue frits (ground blue glass), given elevated levels of alkali elements in some blue glazes when compared with other glaze colors.

XRF analyses of the MFA objects occasionally showed the presence of tin in some glazes, for example in the nineteenth century rustic platter (93.1138, see fig. 2), but the majority were transparent and free of this opacifier. Lead-antimony yellow was detected in one (19.1238, see fig. 5), supporting the conclusion that this is an object made not by Palissy himself, but in an anonymous workshop of the seventeenth century. Nearly all blues in all objects contained nickel and arsenic, elements that have also been identified in Palissy works. At this point, it is not known whether there are any significant differences in blues between Palissy (or among different Palissy creations) and works by later "followers".

Results of SEM/EDS analyses are summarized in Table 1. These are presented for the most part without comment, as not enough detailed analyses have yet been published to determine whether this information is of value with respect to specific questions of attribution and periods of production.

\section{Rustic Platter}

The rustic platter (60.8, see fig. 1), the most "Palissy-like" of the objects in Boston, was the most thoroughly studied. It has a white substrate $\left(65 \% \mathrm{SiO}_{2}, 28 \% \mathrm{Al}_{2} \mathrm{O}_{3},<1 \%\right.$ each of $\mathrm{Na}, \mathrm{Mg}$, $\mathrm{K}$, Ca and Fe oxides). "Extra white" clay ceramic bodies, usually with a little under $1 \%$ iron oxide, are one of three types favored by Palissy ${ }^{25}$; the source of kaolinite-rich clay used in these bodies is not currently known, but may have been southwest France ${ }^{26}$. This highly refractory substrate would have been fired around $900-1100^{\circ} \mathrm{C}$. A fairly abundant amount of small quartz particles were mixed with the clay (mostly less than $0.2 \mathrm{~mm}$ in size, occasionally up to about 0.4 $\mathrm{mm}$; fig. 10), which would have affected its degree of shrinkage and firing temperature to some extent. "Saint-Porchaire" ceramics, produced in France about the same time during which Palissy worked, were made with similar kaolinite-rich clay, the source for which has yet to be identified ${ }^{27}$. 

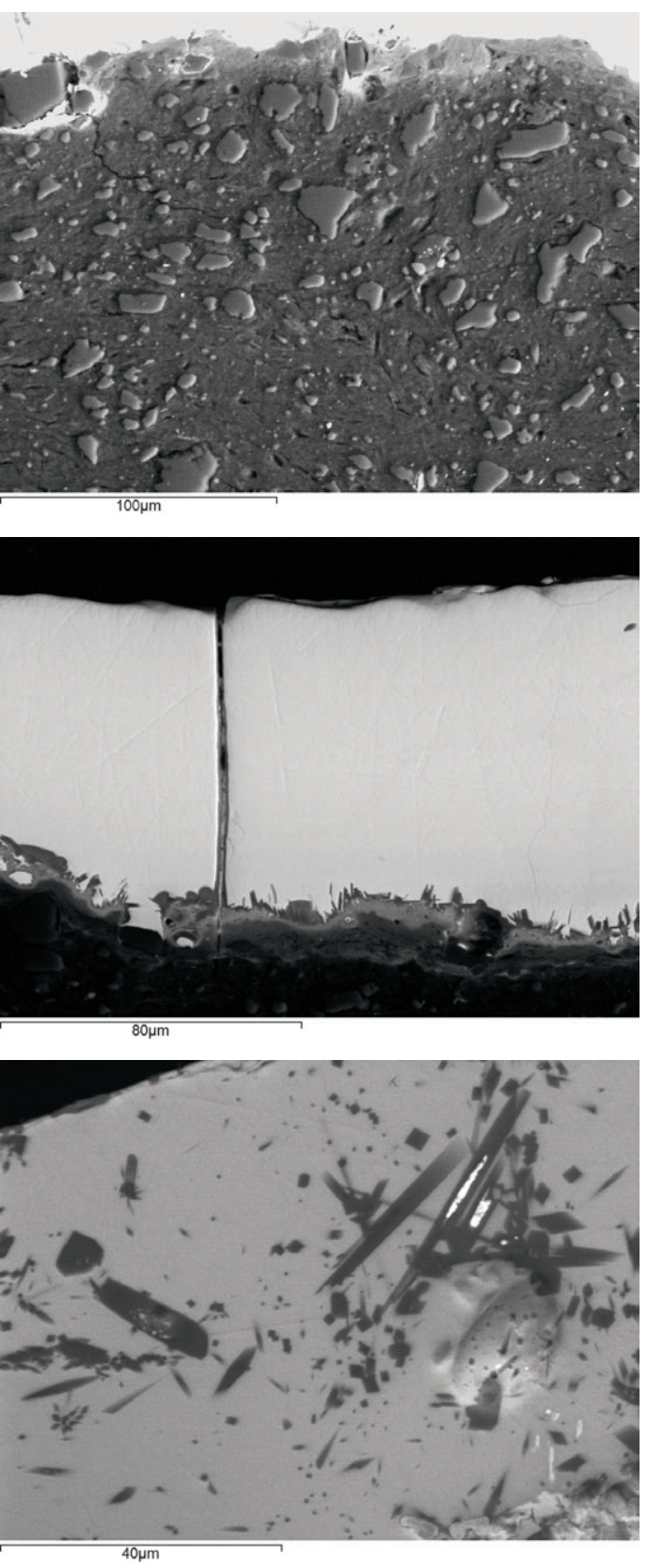

Fig. 10. MFA 60.8 (see fig. 1), sample 7 a, ceramic substrate, with some of lead glaze visible at top (white). Smooth angular gray grains are quartz. (๑) Museum of Fine Arts, Boston.

Fig. 11. MFA 60.8 (see fig. 1), sample 7 a, transparent green glaze, with crack extending through to the substrate. Some crystals are visible at the glaze/substrate interface. Substrate is present at the bottom.

Back-scattered electron photomicrograph; width of field, $0.17 \mathrm{~mm}$. () Museum of Fine Arts, Boston.

Fig. 12. MFA 60.8 (see fig. 1), sample 5, somewhat opaque blue glaze. Numerous crystalline inclusions of various compositions are present, responsible for the opacity. Acicular crystals (dark gray; rich in $\mathrm{Ca}, \mathrm{Mg}$ and $\mathrm{Si}$ ) enclose some bismuth silicate crystals (white). Light gray crystals near lower right are rich in $\mathrm{Ca}, \mathrm{As}, \mathrm{Pb}$, and $\mathrm{Si}$. Back-scattered electron photomicrograph, width of field, $0.09 \mathrm{~mm}$. () Museum of Fine Arts, Boston.
The glazes would have been fired at a lower temperature, perhaps $100-200^{\circ} \mathrm{C}$ below the temperature at which initial firing of the body had been carried out. Some cross sections show cracks in the glaze from slight misfits in contraction rate between body and glaze (fig. 11). A generally quite thin reaction layer is present between body and glaze, containing aluminum-rich crystals formed as aluminum diffused into the glaze from the body during firing. With one exception, the cross sections show fairly thin, transparent glaze layers with no discernible crystalline inclusions and little compositional variation from spot to spot within a given sample, with the occasional exception of increasing aluminum as the interface between glaze and body is approached.

The glazes of this rustic platter are all free of tin oxide. Six of the seven samples exhibited very similar $\mathrm{Pb} / \mathrm{Si}$ ratios, a feature that French research suggests is more typical of "Palissy followers" than of Palissy himself. One blue sample was somewhat opaque due to some large imperfections where ground-up blue colorant apparently did not completely dissolve during firing, as well as numerous complex crystals formed during firing through reaction of colorant components and basic ingredients of the glaze. The blue has a higher silicon content than the other samples. In fig. 12, which shows some of the inclusions, the larger acicular (dark gray) crystals are rich in silicon, calcium, and magnesium, with significant amounts of iron, cobalt and nickel (above what is in the matrix of the glaze). These may be partially reacted bits of a blue frit; at any rate, these crystals contain considerable magnesium, an element nearly absent in the overall glaze, as well as much more calcium than the matrix of the surrounding glaze. The crystals (light gray) at lower right contain lead, silicon, arsenic, and calcium, but no magnesium or significant cobalt, nickel or iron. The arsenic likely originated from a cobalt ore source. The white crystals enclosed in some of the dark crystals appear to be bismuth silicate; the bismuth is also a component of a cobalt ore.

\section{Triangular Graphs - SEM And PIXE}

Some of the properties of the glazes in MFA objects together with previously published research on Palissy and his "followers" are captured in the triangular graphs in figs. 13-15, which show relative amounts of $\mathrm{PbO}, \mathrm{SiO}_{2}$ and minor elements ("five oxides," the sum for $\mathrm{Na}, \mathrm{Al}, \mathrm{K}, \mathrm{Ca}$ and $\mathrm{Fe}$ oxides). The minor elements are for the most associated with non-colorant components of the glaze formulations, although iron was used as a colorant in yellow or orange glazes. (Magnesium, another non-colorant minor element, was not included in all analyses, so is not considered in the graphs.) Although some analyses included in these graphs report iron as $\mathrm{FeO}$ and others as $\mathrm{Fe}_{2} \mathrm{O}_{3}$, the differences in the oxide quantities from the two procedures produce insignificant variations in the graphs, so no conversions to one reporting form have been carried out. Most of the French analyses have been carried out by non-invasive PIXE, a few by electron beam 


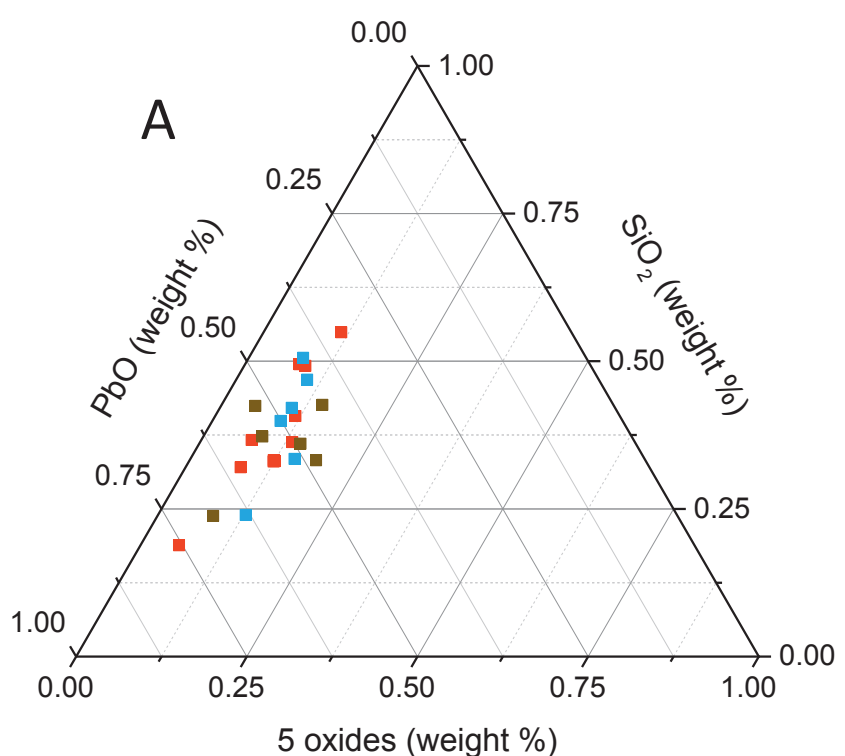

Fig. 13. Relative $\mathrm{PbO}, \mathrm{SiO}_{2}$, and "five oxides" (sum of $\mathrm{Na}, \mathrm{K}, \mathrm{Ca}, \mathrm{Al}$, and $\mathrm{Fe}$ oxides) for Palissy glazes. Red squares: representative examples excavated from Palissy's workshop; analyses of cross sections by electron beam microprobe $\mathrm{Fe}$ as FeO. Blue squares: platter in Lyon. Brown squares: related platter in the Louvre, analyses by non-invasive PIXE, $\mathrm{Fe}$ as $\mathrm{Fe}_{2} \mathrm{O}_{3}$. ( ) Museum of Fine Arts, Boston.

microprobe on cross sections. There may be discrepancies between PIXE and microprobe (or SEM/EDS) analyses of cross sections, but nevertheless the comparisons of results from the different analytical approaches are useful.

The graphs clearly show the range of variations in $\mathrm{Pb}$ and Si that Bouquillon et al. report as quite characteristic of Palissy's work ${ }^{28}$ : $\mathrm{PbO}$ ratios range from about 0.34-0.75. Somewhat less extensive variations are found in the "Griffin Master" glazes: $\mathrm{PbO}$ from about 0.43-0.68. The "Griffin Master" data comprises six stylistically-related ceramics perhaps produced in the same seventeenth century workshop; the "artist" has recently been renamed "Master of the Dragon" ${ }^{29}$. As already noted, the MFA rustic platter samples show, with one exception, very similar $\mathrm{PbO}$ content (0.60-0.68).

The graphs show that while "five oxides" contents vary, there do not seem to be consistent differences between the works of Palissy and "followers", although Palissy works again show greater overall ranges in these elements than those of followers. These graphs only highlight some broad features; as yet, not enough detailed studies of individual objects have been published to ascertain clear distinguishing characteristics in compositions between the work of Palissy and later "followers".

Ongoing research on boron in glazes, which is at an early stage, indicates that levels of this element may provide a reliable tool to (sometimes) distinguish Palissy's work from

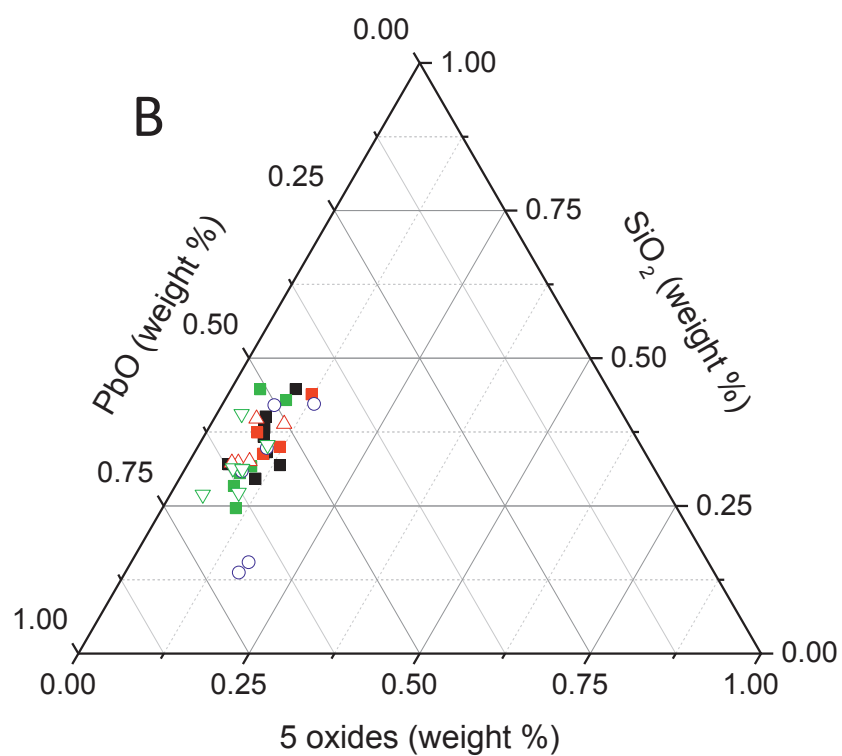

Fig. 14. Relative $\mathrm{PbO}, \mathrm{SiO}_{2}$, and "five oxides" (sum of $\mathrm{Na}, \mathrm{K}, \mathrm{Ca}, \mathrm{Al}$, and $\mathrm{Fe}$ oxides) for "Griffin Master" platter glazes. Filled red squares: Cleveland Museum of Art; filled black squares: Louvre; filled green squares: Écouen 1; open red triangles: Écouen 2; open upside-down triangles: Écouen 3; open blue circles: Sevres. Analyses by non-invasive PIXE, Fe as $\mathrm{Fe}_{2} \mathrm{O}_{3}$. (C) Museum of Fine Arts, Boston.

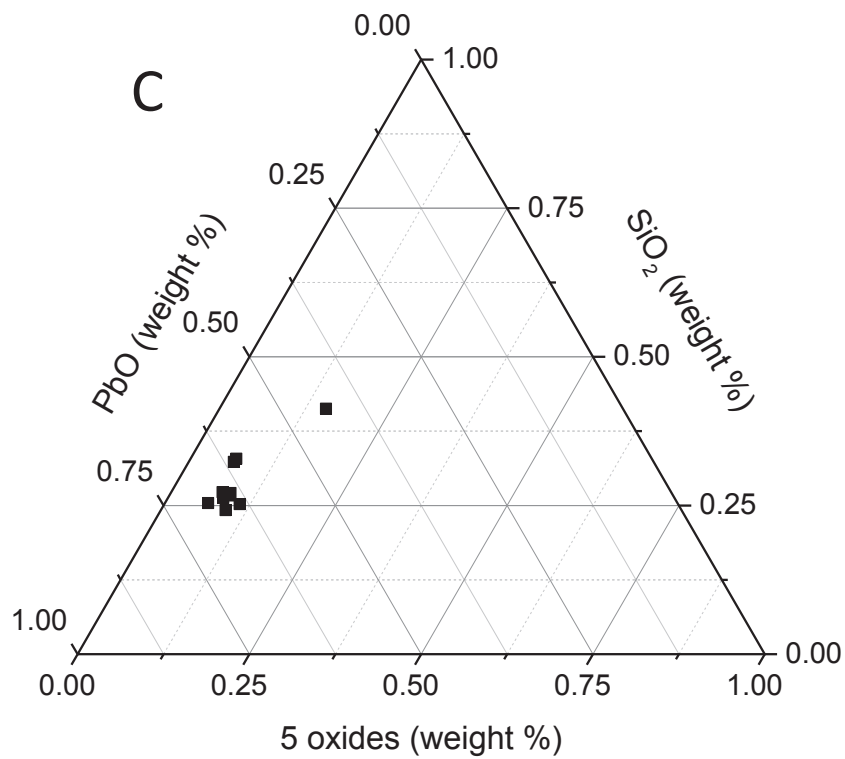

Fig. 15. Relative $\mathrm{PbO}, \mathrm{SiO}_{2}$, and "five oxides" (sum of $\mathrm{Na}, \mathrm{K}, \mathrm{Ca}, \mathrm{Al}$, and $\mathrm{Fe}$ oxides) for MFA 60.8 (fig. 1). Analyses of cross sections by SEM/EDS (see Table 1), Fe as FeO. C Museum of Fine Arts, Boston. 
Table 1. SEM/EDS analyses of cross sections of glazes.

Figures are weight percentages of the oxides, normalized to $100 \%$ for the elements detected.

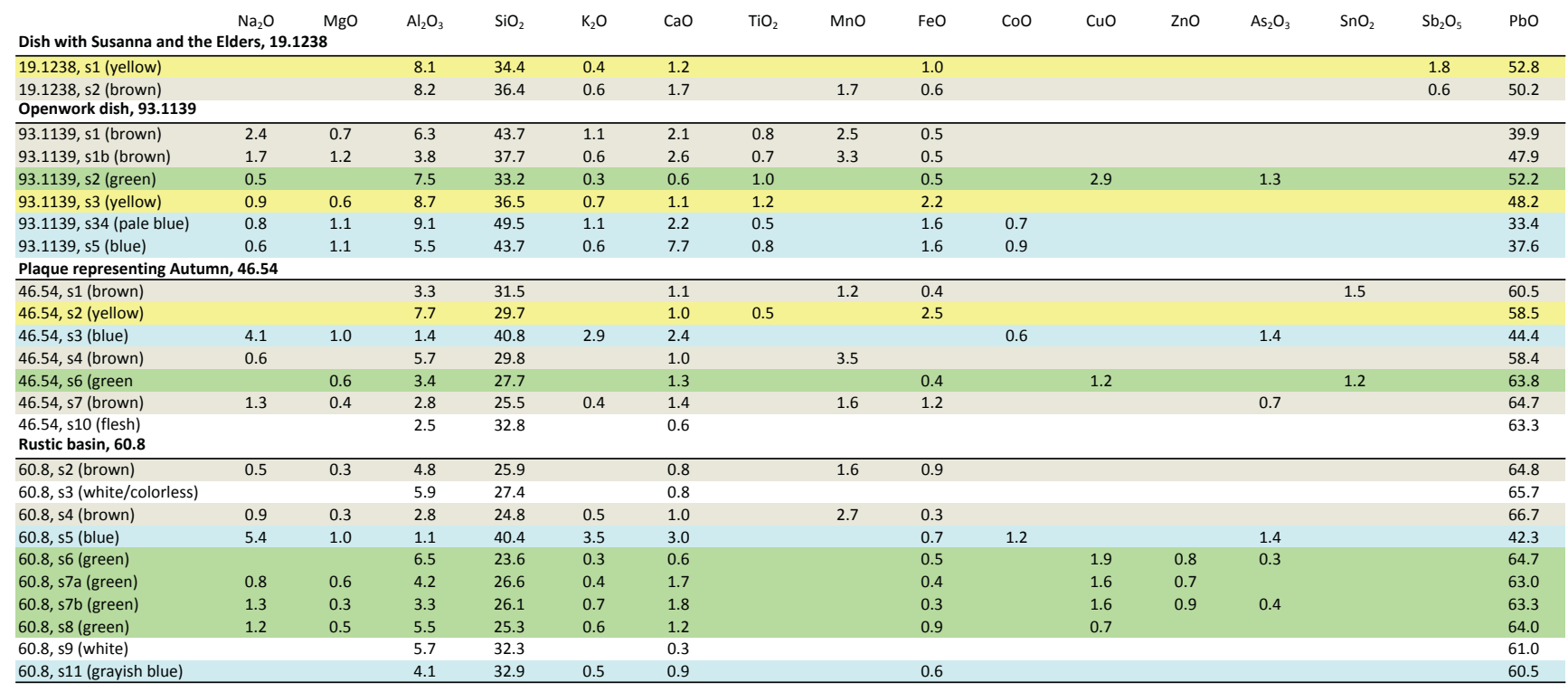

Most figures in the table are average of three large area analyses on the sample, each carried out for 100 seconds (live time).

A variety of standards were used for quantifying the results, including Corning reference glasses and minerals. Default standards for metallic elements were used. The set of standards give reasonably accurate results for Corning glass standards A-D.

Detection limits for most oxides under the conditions of these analyses are about $0.2 \%$, but higher for tin, antimony and lead (about $0.4 \%$ ).

If an amount is not listed, that element is absent (or present below its detection limit).

Peaks for arsenic and magnesium overlap, and when both are present, as appears to be the case in some of the samples, amounts of both cannot be very accurately determined.

the seventeenth-century production. The MFA cross sections were analyzed with the accelerator AGLAE used in the noninvasive analyses on ceramics reported by Bouquillon et al. ${ }^{30}$ The PIGE analyses were complicated by the small size of the MFA's cross sections, many of which were smaller than the standard beam size of the instrument, and the results are currently under evaluation. But it is expected that the results could be an invaluable aid in firmly assigning some of the MFA objects to later "followers of Palissy". Given the usefulness of quantitative data on boron content, other analytical techniques for characterizing this element in cross sections are also being explored.

\section{Conclusion}

In looking at the collection of Palissy ware or ceramics associated with Palissy in the MFA's collection, it is likely that none was made by Palissy, despite the early attributions. XRF and SEM/EDS analyses strongly suggest that some can be attributed to "followers of Palissy", and dated probably to the seventeenth century. Analytical results on others are more equivocal. Of the two rustic basins, one has long been known to be a nineteenth-century imitation; this was not sampled for analysis but XRF showed that the glazes contained both $\mathrm{Sn}$ and non-Sn glazes. The recent revisions of Palissy attributions has led to an appreciation of the active production of leadglazed ware by "Palissy's followers", who are now receiving greater attention in their own right. Ongoing research on glazes in particular may further aid in attributions, particularly when boron can be included in the elements analyzed. 


\section{Endnotes}

1. For example, see William Chaffers, Marks and Monograms on Pottery and Porcelain (London: J. Davy and Sons, 1876), p. 180. See also Amico, 1996, p. 127-128.

2. See Marshall P. Katz and Robert Lehr, Palissy ware : nineteenth-century French ceramists from Avisseau to Renoleau (London and Atlantic Highlands, NJ: Athlone Press, 1996).

3. See correspondence dated August 24, 2017 from Elena Ivanova, Hermitage Museum, in MFA object file (60.8).

4. Swarzenski's comments are preserved in the object file for 60.8 in the Art of Europe department at the MFA.

5. Amico, 1996, p. 216.

6. Second Catalogue of the Collection of Ancient and Modern Works of Art Given or Loaned to the Trustees of the Museum of Fine Arts (Boston: Alfred Mudge and Son, 1873), p. 62, cat. 410 The plate was sold at Sotheby Parke-Bernet, New York, sale n 3953 (February 18, 1977), lot 18 . The name of the original donor of the plate to the Athenaeum is unfortunately not recorded. A rustic basin evidently cast from the same mold is in the Metropolitan Museum of Art (53.225.52).

7. Boston Post (September 2, 1876), p. 4. Jones, McDuffee and Stratton Co., founded in 1810, were importers and retailers of glass and ceramics with a large showroom in downtown Boston. See Regina Lee Blaszczyk, Imagining Consumers. Design and Innovation from Wedgwood to Corning (Baltimore and London: The Johns Hopkins University Press, 2000), p. 34-35, p. 67-68.

8. Catalogue of Works of Art Exhibited on the Second Floor: Paintings, Drawings, Engravings, and Decorative Art, Winter, 18881889 (Boston: Museum of Fine Arts, 1889), p. 71.

9. "Rediscovered a Lost Art: Famous Palissy Ware Reproduced by a Boston Man F. B. De Blois," Boston Daily Globe (August 2, $1903)$, p. 36. The authors are grateful to Courtney Harris for bringing this reference to their attention.

10. In 1852, Boston publishers Ticknor, Reed and Fields issued a two-volume edition of Henry Morley, Palissy the Potter. Writing in the Boston Post on October 29 that year, a local reviewer supposed that "few of this generation have heard of Palissy..." Five years later, Cecilia Brightwell declared her intention to "draw attention to his religious character" in Palissy the Potter. A True Tale (Boston: Ira Bradley and Co., 1858), published by a firm that specialized in popular religious works for young readers. Other standard reference works on Palissy by Cap (1844), Sauzay and Delange (1862), Tainturier (1863), and Audiat (1868) were owned by local collectors and libraries.

11. Conservation treatment of this dish was carried out by Katherine Langdon in 2014.

12. See La Collection Spitzer. Antiquité, Moyen Age, Renaissance (Paris: Maison Quantin, 1891), vol. 2, p. 153, cat. 32, and Catalogue des Objets d'art et de Haute Curiosité, Paul Chevalier and Charles Mannheim, auctioneers, Paris (17 April-16 June, 1893), p. 109 , cat. 620 . The dish was a gift in October 1893

13. Obituary of William Hastings Hughes, New York Times (April 21, 1907), p. 9 .

14. See Amico, 1996, p. 124. Regarding the relationship between potters and sculptors, see the article by J. Denis-Dupuis in this volume.

15. Curatorial justification in the object file for 41.106 in the Art of Europe department.

16. Conservation treatment of the plaques was carried out by Michaela Paulson in 2014.

17. Jessica Denis-Dupuis has identified the location of this dish, which was formerly in the Durand collection at the Louvre (MR 2328) before its transfer to Guéret in 1910. See Louis Clement de Ris, Notice des Faiences Françaises, musée du Louvre, Conservation des objets d'art du Moyen Âge et de la Renaissance, Serie H (Paris: Charles de Mourgues Frères, 1871), cat. H. 84. A third dish with this subject, then in the collection of E. Cliquot but now unlocated, is mentioned in Gazette des Beaux-Arts, vol. 14 (1876), p. 92.

18. Qualitative analyses were carried out with a Bruker Artax $\mu$-XRF spectrometer. A Rh tube with $0.65 \mathrm{~mm}$ collimated beam was used for all analyses, which were carried out at $40 \mathrm{kV}$.

19. Polished cross sections, mounted in epoxy resin, were analyzed with a JEOL JSM6460LV scanning electron microscope with an attached Oxford Instruments energydispersive X-ray spectrometer. Quantitative analyses were carried out using a variety of glass and mineral standards; XPP matrix corrections were computed with Oxford INCA software. The SEM was operated at $20 \mathrm{kV}$ with a beam current of about 1 nanoamp.

20. Bouquillon et al., 2005.

21. Bouquillon et al., 2017.

22. Perrin et al., 1997.

23. Bouquillon et al., 2004a, 2017.

24. Zucchiatti et al., 2006.

25. Bouquillon et al., 2004b, 2005.

26. Tite, 1996.

27. Tite, 1996.

28. Bouquillon et al., 2017.

29. Plaziat, 2011.

30. Bouquillon et al., 2017.

\section{Bibliography}

Amico L. N., 1996, Bernard Palissy: In Search of Earthly Paradise, Flammarion, Paris.

Bouquillon A., Castaing J., Dufournier D., Bergeret J., 2004a, «Le problème particulier des "suites de Palissy" du Pré-d'Auge ", Technè, n 20, p. 83-91.

Bouquillon A., Leconte O., 2004b, « Relire Palissy à la lumière des analyses ", Technè, n 20, p. 69-76.

Bouquillon A., Castaing J., Leclaire A., Ravoire F., Leconte O., 2005, "Palissy ceramics: elemental analysis and origin of clays", in Understanding People Through Their Pottery: Proceedings of the 7 th
European Meeting on Ancient Ceramics (EMAC'03). Instituto Tecnológico E Nuclear, Lisbon, Portugal.

Bouquillon A., Barbe F., Lehuédé P., Castaing J., Crépin-Leblond T., 2013, "Bernard Palissy: scientist and potter of the Renaissance in France", in Saunders D., Spring M., Meek A. (eds.), The Renaissance Workshop: The Materials and Techniques of Renaissance Art, Archetype Publications in association with the British Museum, London, p. 152-159.

Bouquillon A., Castaing J., Barbe F., Paine S. R., Christman B., Crépin-Leblond T., Heuer, A. H., 2017, "Lead-glazed Rustiques Figulines (Rustic Ceramics) of Bernard Palissy (1510-90) and his followers", Archaeometry, vol. 59, issue 1, p. $69-83$.

Castaing J., Menu M., 2006, "Analysis of art works and nuclear physics at the laboratory of Centre de recherche et de restauration des musées de France", Nuclear Physics News, 16, p. 4-10.

Christman B., Heuer A., Castaing J., 2004, "Palissy ceramics in the collection of the Cleveland Museum of Art," Technè, $\mathrm{n}^{\circ} 20$, p. 92-95.

Perrin I., Velde B., Mac Arthur D., 1997, "Les glaçures de Bernard Palissy: une technique originale d'opacification", Technè, n 6, p. 58-64.

Plaziat J.-C., 2011, "Bernard Palissy (15101590) and the French geologists: a critical reappraisal concerning the founding naturalist and his rustic ceramics", Bulletin de la Société géologique de France, t. 182, n 3, p. 255-267.

Tite M., 1996, "Comparative study of the production technology for 'SaintPorchaire' and related European ceramics", in Barbour D., Sturman S. (eds.), Saint-Porchaire Ceramics, Studies in the History of Art 52, Monograph Series II, National Gallery of Art, Washington D.C., p. 99-106.

Zucchiatti A., Bouquillon A., Katona I., D'Alessandro A., 2006, "The 'Della Robbia blue': a case study for the use of cobalt pigments in ceramics during the Italian Renaissance", Archaeometry, vol. 48, p. 131-152.

\section{Acknowledgments}

In the preparation of this essay, the authors gratefully acknowledge the assistance of Courtney Harris, Curatorial Research Fellow for decorative arts and sculpture in the Art of Europe department at the Museum of Fine Arts and Michele Derrick, Shorr Family Scientist at the MFA, who carried out FT-IR and XRF analysis. The authors are also grateful to Anne Bouquillon, Claire Pacheco and Quentin Lemasson at the C2RMF for their collaboration in carrying out the PIGE analysis.

Financial support by the Access to Research Infrastructures activity in the 7th Framework Programme of the EU (CHARISMA Grant Agreement n. 228330) is gratefully acknowledged. 